\title{
Erotismo y mediatizaciones Revistas femeninas en la Argentina de la década del 60
}

\section{MARÍA LAURA SCHAUFLER}

mlaura31@gmail.com - Centro de Investigaciones en Mediatizaciones, Universidad Nacional de Rosario (CIM-UNR), Argentina.

Fecha de recepción: 29 de octubre de 2017

Fecha de aceptación: 30 de noviembre de 2017

\section{RESUMEN}

El presente artículo traza un recorrido históricocultural acerca del problema del erotismo en la prensa femenina argentina de la década del 60. Ello supone una contextualización dentro de un marco de los estudios culturales, de géneros y sexualidades y las investigaciones sobre mediatizaciones. La categoría de erotismo ha jugado un papel silencioso en el marco de las ciencias sociales. Como tópico se ha mantenido en los márgenes quizás por el peso de la herencia de la cultura religiosa que lo ha definido como un tema prohibido. Neutralizada, la categoría a menudo ha estado solapada tras la sexualidad $-\mathrm{y}$ ésta última asociada estrechamente a la dualidad sexual o de los sexos-.

En el plano discursivo y en el marco de la cultura de masas constituyó un tópico de disputa simbólica en la década del 60. Lo decible y lo visible respecto al erotismo sufrió mutaciones, hilvanándose una cesura que resignificóla problemática, redefiniendolo indecible, dentro de la configuración de una época. Los regímenes semiótico-discursivos indicaban no sólo qué podía y qué debía ver la sociedad acerca de lo erótico sino también cómo debía verlo. Las construcciones discursivasysemióticas en la prensa femenina configuraban una visibilización moderada de este aspecto de la vida social.

PALABRASClAVE: erotismo, feminidad, revistas, sesentas, censura.

The present article is aimed at situating the problem of eroticism in the decade of the 60s in Argentine women's press. This implies a historical-cultural contextualization within a framework of cultural studies, genres and sexualities and mediatizations research. The category of eroticism has played a silent role in the social sciences. As a topic has been kept in the margins perhaps because of the weight of the heritage of religious culture that has defined it as a prohibited subject. Neutralized, the category has often been undermined by that of sexuality -closely associated with sexual or gender duality-.

At discursive level and within the framework of mass culture, it was a topic of symbolic dispute in the 1960s. The decible and the visible about eroticism underwent mutations, weaving a caesura that resignificated the problematic, redefining the unspeakable, within the configuration of an era. Semiotic-discursive regimes indicated not only what society could and should see about eroticism, but how it should be viewed. Discursive and semiotic constructionsinfeminine press constituted a moderate visualization of this aspect of social life.

KEYWORDS: eroticism, femininity, magazines, sixties, censorship. 


\section{UN EROTISMO DEÉPOCA}

El erotismo ha sido un tópico quehajugado un papel silenciosoyseha mantenido en los márgenes de las ciencias sociales quizás por el peso de la herencia de la cultura religiosa que lo ha definido como un tema prohibido, maldito (Vance, 1989; Campillo, 1996; Marzano, 2006; Muchembled, 2008; Bataille, 2010; Barrancos, 2011; Bruckner, 2011). Neutralizada, la categoría a menudo ha estado solapada tras la sexualidad, y ésta última asociada estrechamente a la dualidad sexual o de los sexos. Eminentemente asociado a los sentidos del placer y del deseo sexual, el erotismo como discurso se constituye a sí mismo como objeto de deseo, busca interpelar al placer y habilita el disfrute, sin pretensiones de neutralidad, jugando con la transgresión de una experiencia juzgada como maldita o culpable (Bataille, 2010 [1957]).

En el plano discursivo constituyó un tópico de disputa simbólica en la década del 60. Lo decible y lo visible respecto al erotismo sufrió mutaciones, hilvanándose una cesura que resignificó la problemática, redefiniendo lo indecible, dentro de la configuración de una época:

Podría decirse que, en términos de una historia delasideas, una época se define como un campo de lo que es públicamente decible y aceptable -y goza de la más amplia legitimidad y escucha- en cierto momento de la historia, más que como un lapso temporal fechado por puros acontecimientos, determinado como mero recurso ad eventa (Gilman, 2003, p. 36).

Los regímenes semiótico-discursivos indicaban no sólo qué podía y qué debía ver la sociedad acerca de lo erótico, sino también cómo debía verlo. Las construcciones discursivas y semióticas en la prensa femenina configuraban una visibilización moderada de este aspecto de la vida social.

A diferencia del amor o de la sexualidad que han sido abordados por investigaciones empíricas en torno a la prensa femenina de la década del 60, especialmente desde los estudios de género (Carrascal, 2010; Trebisacce, 2010; Cosse, 2011; Bontempo, 2011; Ballent, 2011), el problema del erotismo ha quedado marginado de los estudios de las revistas femeninas. Específicamente, el tópico ha sido analizado en publicaciones relacionadas al porno y su censura en Argentina (Eidelman, 2015) y, de manera paradigmática, en Estados Unidos con la producción del modelo semiótico de la revista Playboy (Preciado, 2010).

Definida como una década frenética (Pujol, 2002), los años 60 conformaron un período de corte cultural, que "mostraba una suerte de volcanes en ebullición, estampidas que sacudían no sólo lo público" (Barrancos, 2010, p. 212). Durante esos años de desbordes, se manifestaba la certeza de la existencia de los cambios culturales asociados a la modernización y a los aconteceres internacionales junto a la incertidumbre sobre el sentido que éstos asumirían.

La época trajo aparejada una sensibilidad emergente, una estructura de sentimientos que atravesó el mundo, que puso en discusión temas relaciona- 
dos al erotismo, como el amor, la sexualidad, las relaciones de género con el apogeo de la segunda ola del feminismo (Gilman, 2003). La nueva sensibilidad, soñada por Herbert Marcuse (2010 [1953]), se relacionaba con "una cultura de las emociones y también una 'cultura afectiva"' (Lenarduzzi, 2012, p. 221).

La década fue prontamente mitificada, de manera prolífica, como años de cambios, transgresiones y censuras, irrupciones y disrupciones, experimentación y sensación de estar construyendo la historia (Kozak, 2006). Sus años remiten a un arsenal de imágenes globales -como la píldora anticonceptiva, las comunidades hippies y el Mayo del 68-, asociadas a lasideas de juventud y rebelión frente a los mandatos familiares tradicionales y la moral sexual instituida (Cosse, 2010). El proceso de mitificación quellevó a estos signos a transformarse en emblemas con valor universal (Preciado, 2010) atravesó la construcción de un imaginario erótico masculino que perduraría con el tiempo.

Los cambios de la época en la construcción semiótico-discursiva del erotismo conformaron un motor simbólico que seguiría funcionando y transformándose durantelas décadas siguientes, también construyó varios mitos queincluso hoy se consumen. Fue, por ejemplo, la era dorada de Playboy, de la imagen de Marilyn Monroe, como uno de los mitos genérico-sexuales más significativos del sigloXX, y también dela imagen de muchos galanes masculinos, como Alain Delon a nivel internacional o Sandro a nivel local. Es decir, la década constituyó un corte cultural que en sus múltiples expresiones hoy resulta viejo y joven a la vez (Pujol,2002). No coincide tanto con una década cronológica, sino que señala la simultaneidad de una serie de dinámicas culturales, políticas y sociales que la configuraron y que seguirían signando la historia cultural argentina.

En el plano de las mediatizaciones, los años 60 fueron testigos del boom editorial en el país. Las revistas proliferaban y, especialmente, las revistas femeninas se multiplicaban y modernizaban.

En el plano político, el país navegó entre períodos democráticos inestables y dictaduras, signados por la deslegitimación de las instituciones republicanas y la creciente presencia de las Fuerzas Armadas con su rol tutelar ${ }^{1}$. En este sentido, el año 1969 supuso un corte, no sólo cronológico, cuando la represión y la censura del gobierno de facto del General Juan C. Onganía, entre 1966 y 1970, se ensañó más con las expresiones eróticas en los medios de comunicación.

El año estuvo marcado por la radicalización política tras el Cordobazo y el Rosariazo en mayo de 1969. Se signó así la clausura de una época:

Si una época se define por el campo de los objetos que pueden ser dichos en un momento dado, la clausura de ese período está vinculada a una fuerte redistribución de los discursos y a una transformación del campo de los objetos de los que se puede o no se puede hablar (Gilman, 2003, p. 53).

1 Durantela década trascurrieron: la presidencia de Arturo Frondizi (1958-1962), el gobierno de facto de José María Guido (1962-1963), la presidencia de Arturo Illia (que comenzó en 1963 y fue depuesta por las Fuerzas Armadas en 1966) y el mandato del Gral. Juan Carlos Onganía, quien ejerció el poder hasta 1970. 
A fines de la década, mientras la coerción dictatorial imponía por la fuerza objetos de discurso y silenciaba otros, la configuración de lo erótico mutaba a la par de los cambios sociales y políticos que se avecinaban con la llegada de la década del 70.

\section{MEDIATIZACIONES SESENTISTAS}

El desenvolvimiento de los medios de comunicación en la década del 60 fue un fenómeno especialmente relevante en el plano cultural (Cosse, 2006), al tiempo que se desarrollaba un mercado trasnacional de productos culturales que favorecía la circulación de ideas, modas y tendencias. Dentro del auge de la industria cultural, la televisión se consolidó como industria (Varela, 2005) y el lugar de los medios masivos de comunicación llegó a concebirse como parte indisociable de los cambios que se estaban produciendo, debido a su creciente expansión y a la idea generalizada de que lo más contemporáneo pasaba en gran medida por ellos. En el campo periodístico y académico esto implicó una postura autorreflexiva respecto del espacio quelos medios ocupaban y también una crítica respecto de cuálera la dirección dominante que adquirían. El interés por los medios masivos aumentó y sus productos pasaron a ser estudiados en sí mismos como activos constructores de la vida social (Kozak, 2006).

La convergencia del proceso de modernización y renovación cultural, la aparición de un núcleo nuevo de intelectuales de izquierda y la radicalización política constituyeron las condiciones de emergencia de un incipiente campo de estudios de la comunicación (Diviani, 2010)². Con la renovación y la expansión de las ciencias sociales, las críticas desde la academia al sistema de medios no demoraron en llegar. En torno a la comunicación de masas se desarrolló una perspectiva bastante apocalíptica que la asociaba a la cultura norteamericana, opuesta a la cultura nacional, más relacionada al arte o a una cultura popular "auténtica". Juzgada como mediocre, la cultura de masas parecía exigir una toma de posición por parte de los intelectuales del campo cultural (Varela, 2005). El proceso de trasnacionalización de la industria cultural fue criticado como expresión de la dependencia de los países no desarrollados.

La tendencia a pensar la comunicación de modo instrumental, en términos

2 En momentos dela formación delos estudios de comunicación en Argentinay con un campo intelectual atravesado por una dimensión fuertemente política (Gilman, 2003), se gestaron líneas de investigación ligadas al problema de lo ideológico y lo político. Héctor Schmucler, Armand Mattelart, Aníbal Ford, Heriberto Muraro, Oscar Masotta, Oscar Steimberg y Jorge Rivera fueron exponentes de este desplazamiento de las inquietudes literarias o psicosociológicas dela conducta hacia el interés por artefactos culturales relacionadosalos medios masivos ylos productos simbólicos denominados populares y de masas. La ideología fue una preocupación central de los estudios de esa época. Los estudios semiológicos -en vinculación con la filosofía, el estructuralismo y el marxismo- daban un lugar central a la política, con las recepciones teóricas de Althusser y de Gramsci (Verón, 1984). Había cobrado un fuerte valor el trabajo empírico ligado a la expansión de las Ciencias Sociales y se habían incorporado lecturas de la Mass Communication Research, también de Marshall McLuhan, donde los medios pasaban a ser percibidos como ambientación antes que instrumento de información o difusión (Varela, 2005). En décadas posteriores, una mirada reduccionista tendería a asociar los estudios de comunicación de la década del 60 con la hipótesis de la manipulación. Devenida sentido común académico y con una perspectiva evolucionista, se criticaría la inocencia e infantilidad de aquellas teorías. 
de gestión y marketing, se remonta a esta década, cuando el concepto se extendió por el mundo de los negocios, después de la Segunda Guerra Mundial. Una concepción teleológica, apoyada en la concepción "ingenua" de que "todo se comunica", implicó el auge de un enfoque instrumental que apostaba al dominio de las herramientas como única garantía de la eficacia de la comunicación (Mattelart, 1991). En este marco, el poder de los medios de comunicación también fue mitificado. Las reflexiones se caracterizaron por interpretarlos desde una concepción representacional, es decir, los medios eran entendidos como instrumentos orientados a la comunicación y que funcionaban como espejos, más o menos deformantes, de una realidad exterior a ellos. Frente a esta interpretación, en la década siguiente se afianzarían perspectivas semióticas como la de Eliseo Verón (1984) que propondrían una visión de los medios como dispositivos de producción de sentido ${ }^{3}$.

\section{BOOM EDITORAL}

En Argentina, la esfera cultural asociada al proceso de modernización tuvo sus manifestaciones en el crecimiento de agencias de marketing y publicidad, el posicionamiento de la televisión como medio y en el boom editorial. El crecimiento de la industria editorial tuvo una importancia notoria en las innovaciones del campo cultural (Pujol,2002). Elmercado de revistas se dinamizó con la renovación del estilo periodístico, la di-

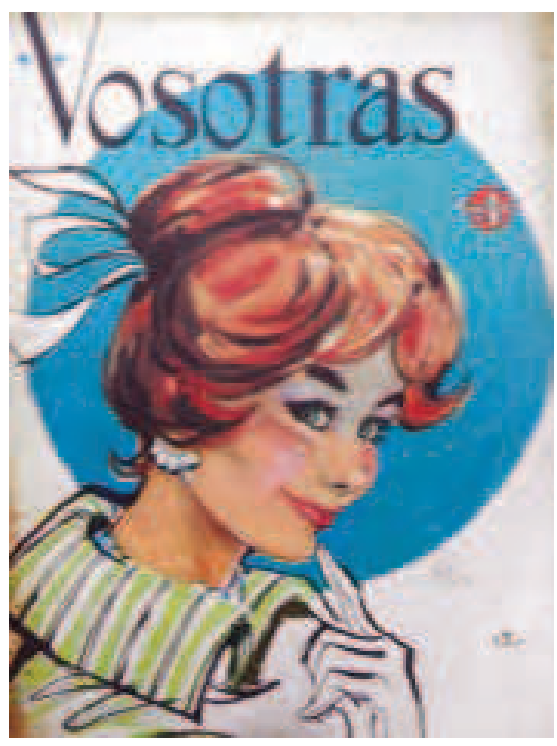
versificación de la oferta y las dinámicas competitivas que apuntaban a captar un público en expansión. Su lectura estaba ya integrada a las prácticas culturales de amplios sectores sociales, en especial dela clase media y trabajadora (Cosse, 2010).

El periodismo gráfico supuso una nueva concepción estética de los medios, y la fotografía iba tomando cada vez mayor importancia en detrimento de la ilustración (figura 1) que abandonó las portadas a principios de la década ${ }^{4}$.

Figura 1. Tapa de la revista Vosotras, $\mathrm{n}^{\circ} 1244,8 \mathrm{de}$ octubre de 1959.

3 La comprensión veroniana de los medios de comunicación como concepto sociológico y no tecnológico implicó entonces: "distinguir definitivamente los soportes tecnológicos (que interesan a los ingenieros de telecomunicaciones) de los medios que la sociedad construye a partir de ellos, y de los dispositivos propiamente dichos, que sólo se pueden definir por su modo de inserción en la semiosis social generalizada por el medio" (Verón, 2004, p. 14). El concepto de medios pasó a designar, desde entonces, desde una mirada sociosemiótica, un conjunto constituido por una tecnología sumada a las prácticas sociales de producción y apropiación de esta tecnología, cuando hay acceso público a los mensajes (Cingolani, 2008).

4 Las imágenes se presentan a título ilustrativo. No se ahondará aquí en un análisis semiótico de las mismas. 
Las fotos en la tapa, un nuevo tipo de diagramación y el uso de papel para ilustración eran los nuevos recursos de diseño de la comunicación. Comenzaron a utilizarse imágenes inclinadas, con foco en detalles, intervenidas o recortadas con formas geométricas que potenciaban el movimiento y la apariencia moderna, junto al patchwork o montaje de fragmentos distintos (figura 2).

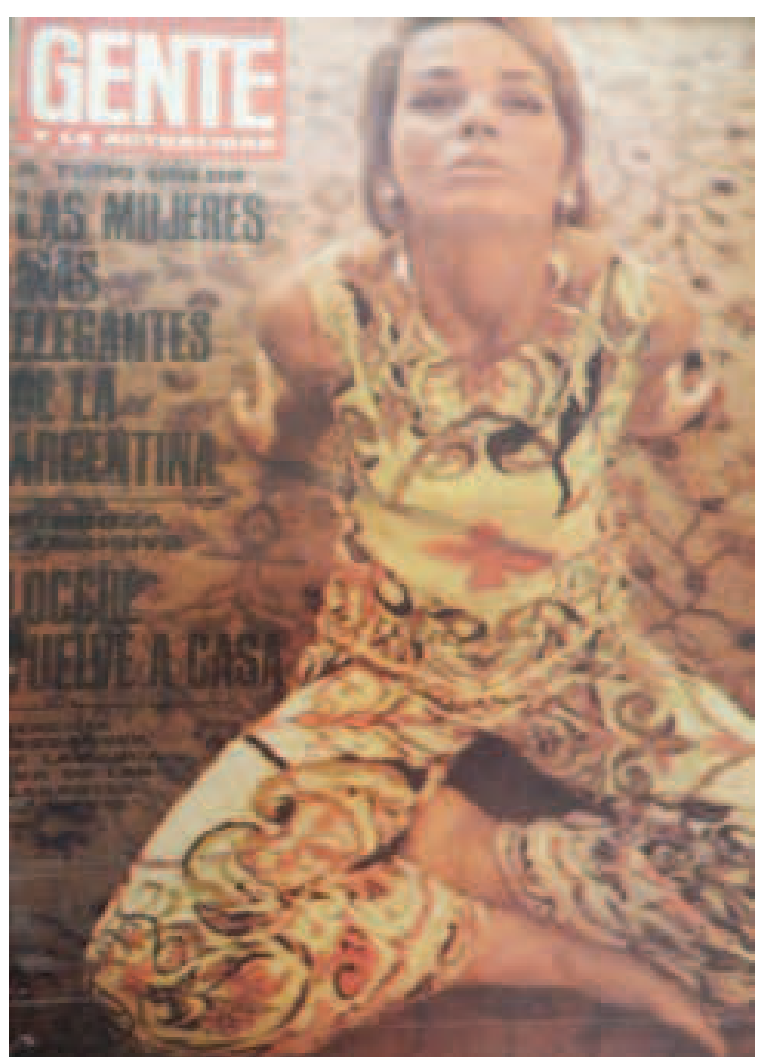

Figura 2. A todo color. Tapa de la revista Gente no 179,26 de diciembre de 1968.

La renovación periodística se dirigía al público con un estilo de escritura supuestamente imparcial y cómplice. La experiencia narrada del periodista se posicionaba como el mejor material de una nota: "Para el lector, el efecto era gratamente literario, en un tiempo en el que la literatura gozaba de gran prestigio" (Pujol, 2002, p. 84).

Los redactores muchas veces eran profesionales o escritores reconocidos. El estilo periodístico era directo, ágil y fresco, con títulos atractivos que buscaban interpelar a los lectores desde un tono coloquial, intimista, incluso algo irreverente. La actualidad pasaba por las revistas, con las mutaciones sociales, culturales y políticas que hicieron de los años 60 una época. Eran habituales las notas sobre temas controvertidos como el divorcio, la educación sexual, las píldoras anticonceptivas, las relaciones amorosas, desde los discursos de la sexualidad en boga, influidos por el psicoanálisis y la sociología.

En el plano cultural, la renovación periodística apoyó las vanguardias -los happenings del Di Tella, el cine de autor y la literatura latinoamericana-. Las revistas parecían asumir el objetivo de educar y moldear los gustos culturales. Lo nacional se articulaba con lo internacional, la noticia local con el acontecimiento mundial; las innovaciones culturales solían legitimarse mediante referencias a figuras o realidades extranjeras. Los horizontes de referencia eran Europa y Estados Unidos. 
Por entonces también se produjo un importante acercamiento de mujeres a las redacciones. Las periodistas eran la avanzada femenina (y en muchos casos, feminista) sobre un terreno tradicionalmente copado por varones. No obstante, como relata Carlos Ulanovsky (1997), ninguna publicación femenina era dirigida por mujeres ${ }^{5}$. Las redacciones, como la de la revista Claudia, dejaban a los varones las responsabilidades de las críticas literarias y cinematográficas, los grandes reportajes, las investigaciones y las notas de gran despliegue.

\section{FEMINIDAD HECHA REVISTA}

Destinadas al consumo individual, las revistas femeninas se consideraban como un objeto personal. Por años, Para Ti, El Hogary Vosotras habían sido las típicas revistas de la mujer argentina junto a aquellas publicaciones destinadas mayoritariamente a la costura, el tejido, las manualidades y la cocina, como Chabela, Labores, Cosas Útiles o la revista alemana Burda Moden, ícono de las revistas destinadas a la confección.

Para Ti fue la primera publicación argentina para la mujer. Fundada por editorial Atlántida en 1922, se destinaba a un público lector de madres y amas de casa, a quienes ofreció un diseño, una estructura y un estilo periodístico inalterados durante décadas. Desde sus comienzos definió a sus lectoras como mujeres modernas, reconociendo quelas mujeres circulaban por diversos ámbitos extradomésticos, aunque comprendía que su experticia y su profesión debían ser el hogar y la maternidad (Bontempo, 2011). Se dirigía a lectoras a las que podía interesarles cierto barniz cultural tradicional, con novelas románticas, notas sobre buenos modales y decoración del hogar. Con una tirada semanaly un precio económico, su posicionamiento le otorgaba una parte significativa del mercado, que compartía con Vosotras, revista femenina de editorial Korn, la cual circulaba entre un público de mujeres de clase popular.

En la década del 60 las revistas femeninas dieron un giro. Los magazines norteamericanos habían identificado, y a la vez construido, la emergencia de un nuevo tipo de mujer que combinaba el interés por el trabajo, el estudio y la belleza. Las europeas Marie Clariey Elle yla estadounidense Cosmopolitan reconfiguraron el estilo periodístico. En esta línea, la editorial Abril lanzó Claudia en 1957, posicionada como una revista de carácter moderno y dirigida a mujeres con cierto estatus social. Rápidamente alcanzó tiradas de 120.000 ejemplares mensuales, como Vosotras y Para Ti que se publicaban semanalmente (ADCP, Estadísticas de Revistas de 1963, en Cosse, 2011). Con un mayor precio por unidad y un papel de mayor calidad buscaba distinguirse de sus competidoras del mercado al destinarse a lectoras de la clase media en ascenso.

5 La periodista Norma Osnajanski, que trabajó para la editorial Abril, ha sostenido que se daba un fenómeno que llamó "vampirismo: los hombres conservaban la formalidad de los cargos y las mujeres se hacían cargo de todo el trabajo” (Ulanovsky, 1997, p. 129). 
Bajo este rango también se encontraba Femirama, Enciclopedia Femenina de editorial Codex. Surgida en 1963, alcanzólos 140.000 ejemplares mensuales en 1968 (ADCP, Estadísticas de Revistas de 1968, en Cosse, 2011). Se autoproclamaba como un lugar de saber enciclopédico, científico, técnico, ilustrado. También se dirigía a "mujeres modernas", ya no restringidas alámbito del hogar familiar. Mediantela promoción de un estilo de mujer sofisticada, innovadora, descontracturada, Claudia y Femirama buscaban distinguirse en función de criterios estéticos y culturales. Ofrecían a las lectoras la posibilidad de sofisticarse en el consumo, los gustos y las costumbres. Estas editoriales apuntaban a un público de mujeres a las cuales, simultáneamente, se proponían educarlas ofreciéndoles vías para conocer y sumarse a las nuevas tendencias:

Esto evidenciaba el prestigio adquirido por el argot cultural e intelectual, así como el desconcierto que generaba en un público interesado en manejar esos símbolos de estatus que le eran ajenos. De modo que las innovaciones de las vanguardias culturales y políticas funcionaban como índices de distinción que otros sectores sociales podían querer emular (Cosse, 2010, p. 49).

En este espectro también se ubicaba Karina, un intento de aggiornamiento de editorial Atlántida, tras los pasos de la francesa Elle (Pujol, 2002), que, con calidad gráfica y material literario, ofrecía temáticas como: "La seducción", "La alta moda italiana", "Enciclopedia dedicada a la mujer" (Publicidad Karina, Gente, n 199, p. 15 de mayo de 1969).

La modernización temática de la prensa femenina intentaba desmarcarse del modelo doméstico, sin transgredirlo, con notas que daban por supuesta una sociabilidad desenfadada con la que se identificaba a la mujer moderna. Apuntaba a mujeres adultas y jóvenes, con disposiciones culturales para la apertura al cambio, la actualización, al refinamiento y el cosmopolitismo.

En cuanto al contenido y las tematizaciones, el rol de Claudia ha sido sobreestimado por los estudios de historia de los medios (Ulanovksly, 1997) y también por los estudios de géneros y sexualidades (Cosse, 2011). Las otras revistas femeninas, en distintos momentos, también iniciaron una estrategia de recambio del estilo periodístico. Publicaciones menos prestigiosas como Maribel, de editorial Sopena, surgida en la década del 30 y destinada a un público de menores recursos económicos, también se dirigía a la mujer moderna y publicaba notas sobre temas controvertidos relativos a la sexualidad y las relaciones de pareja, comola anticoncepción, el prototipo de mujer liberada, las nuevas pautas de organización familiar, la extensión de las relaciones sexuales prematrimoniales y los métodos anticonceptivos modernos, especialmente la píldora.

Revistas de corte más tradicionalista, como Para Ti, Vosotras y Cristina podían dar batalla o silenciar los temas referidos a la sexualidad, pero no por ello dejaban de estar plagadas de discursos con contenido erótico. Las narrativas 
rosas, una sección que no podía faltar entre sus páginas, estaban inundadas de discursos acerca del placer y el amor erótico. Asentadas en un "imperio de los sentimientos" (Sarlo, 2011 [1985]), estas publicaciones no eran más pacatas que aquellas surgidas durante la renovación periodística.

Este imperio también era un área por donde se conducían algunas revistas de actualidad como Gente, de editorial Atlántida. Surgida en 1964, se dedicaba a cubrir, de manera colorida y vivaz, la vida amorosa de los personajes del espectáculo y de la farándula. Era una publicación de lectura ligera, menos comprometida con la modernización cultural como Confirmado o Primera Plana, dirigida a un público vasto y heterogéneo (Pujol, 2002). Si bien no lideró la opinión periodística de los años 60 , contaba con un importante público lector ${ }^{6}$.

En torno a la construcción semiótica y discursiva del erotismo, las editoriales no marcaban una gran diferencia que justificase realizar un análisis contrastivo de éstas. Por un lado, todas las revistas femeninas se dirigían a mujeres con intereses que excedían los del ámbito doméstico y que pensaban en su realización personal, laboral o cultural. Por otro, las distinciones dicotómicas entre publicaciones con discursos tradicionalistas y modernizados tampoco eran tales; estas posiciones se enfrentaban pero también se entrelazaban dentro de un mismo ejemplar de revista de cualquier marca. Con el auge porteño del psicoanálisis y la ciencia sexual ninguna revista dejaba al margen las discusiones sobre aspectos que hacían a la vida íntima asociada con lo femenino, como la infidelidad o el divorcio.

Las revistas continuaban publicando los tradicionales tópicos asociados a las preocupaciones propias de una 'mística de la feminidad' (Friedan, 2009 [1963]), comola cocina, la moda, la astrología, la belleza, el hogar, la decoración y las manualidades, ampliando su registro hacia los respectivos a la sexualidad, la psicología, las nuevas costumbres y el trabajo fuera del espacio doméstico. En pequeña medida aparecían las notas de espectáculo y la cultura (música, libros, cine, etc.), y algunas relativas a la política como las atinentes al sufragio femenino. No obstante, la mayor parte de las páginas se las llevaban las narrativas rosas que disputaban el espacio a las notas sobre modas.

Las revistas femeninas fueron un escenario central de la contienda por los sentidos y los alcances de las transformaciones en el plano de las sexualidades y las relaciones de género. Actuaban, de alguna manera, como mediación pedagógica de una serie de cambios que resultaban desconocidos e incomprensibles para muchas lectoras, educadas con principios menos liberales, miedos y tabúes (Felitti, 2010). La puesta en debate informaba de temas silenciados en otros espacios mostraba también las cavilaciones, sentimientos y experiencias por parte de sus lectoras a través de las cartas publicadas, las encuestas y las opiniones de actores, profesionales, expertos o religiosos:

6 En 1969 vendía 196.000 ejemplares (Pujol, 2002) 
La puesta en discusión, como efecto buscado o impensado, de temas controvertidos como el aborto o el uso de las píldoras anticonceptivas, colocó en la arena pública temas que habían estado resguardados a la privacidad delas alcobas, los confesionarios y los consultorios médicos. En las páginas de las revistas y en las pantallas, el público encontró la posibilidad de ampliar la mirada, multiplicar los debates y dar lugar a nuevas prácticas (Felitti, 2010, p. 243).

La prensa femenina y de actualidad difundía información sexual. En esta área una publicación de actualidad distinguida internacionalmente, como la revista Life, reafirmaba su prestigio. Con notas que daban el tono de la época y creaban la ilusión de estar al día con las tendencias de avanzada en el mundo, al que los nuevos sectores medios deseaban pertenecer (Cosse, 2006), difundía modas actuales y modernas de escala internacional; que rara vez eran adjetivadas negativamente y que podían ser entendidas, en todo caso, como excentricidades de las sociedades avanzadas. Permitía a los lectores argentinos enterarse, por ejemplo, dela educación sexual entrelos niños y niñas daneses, la tendencia unisex delos adolescentes en Estados Unidos, las bandas juveniles en Alemania e Inglaterra, la moda nudista en Europa y la noche bohemia neoyorkina.

Pero, más acá de la revista Life, los debates en torno a la sexualidad y el amor en la prensa femenina argentina se hallaban imbricados con viejos valores que al mismo tiempo se actualizaban. En este punto, es posible pensar la productividad política de estos discursos, si bien no eran catalogados como discursos políticos. Las temáticas conformaban la dimensión de lo político, es decir, formaban parte de la dimensión conflictual de la vida social (Mouffe, 2009); y por esta misma politicidad fueron focos de la censura o mesura periodística.

Al final de la década el avance del autoritarismo y la radicalización política introdujeron una fisura en el programa de modernización editorial junto a una censura más encarnizada frente a las expresiones del erotismo. Por otra parte, la característica exclusión de la información expresamente política en las revistas femeninas había hecho que, también a fines de la década, muchas mujeres comprometidas con las movilizaciones políticas despreciaran estas publicaciones, catalogadas como una lectura de peluquería, o las criticaran desde un punto de vista feminista (Trebisacce, 2010).

\section{UNA ÉPOCA JOVEN Y REBELDE}

Las disputas en torno al erotismo, en sus distintas dimensiones, se inscribieron en el marco de diversas polémicas que marcaron la década. Una de ellas fuela pretensión de modernización enfrentada al tradicionalismo, que recorrió la superficie de los discursos de los sesenta: "Las polémicas imperaron en los 60 porque el valor máximo de la época fue la negación crítica. Todo impulso creador se hizo a partir de la negación de lo inmediatamente anterior o de lo contemporáneo diferente" (Gilman, 2003, p. 20). 
Las posiciones modernizadoras se difundían al mismo tiempo en que se fortalecían las acciones represivas del Estado y los discursos tradicionalistas en lucha contra la llamada disolución moral. En el marco de estas discusiones, la juventud se asociaba a la rebelión cultural y política enfrentada al mundo delos adultos, al que se reprochaba su inhibición, su hipocresía y falta de naturalidad.

La rebelión aparecía como marca epocal. Lejos de tratarse de una revolución caracterizada como un acontecimiento excepcional, la rebeldía formaba parte de la cotidianeidad. La juventud pasó a ocupar el centro de la escena mediática, con un protagonismo para muchos inquietante, mientras la vida cultural entraba en ebullición con la renovación estética propuesta por las vanguardias artísticas y el crecimiento de la industria cultural.

Las interrogaciones sobre el estilo de vida y la escala de valores con los que se regía la juventud argentina se convirtió en una moda periodística. Algunas especialistas tranquilizaban a las madres preocupadas, afirmándoles que la rebelión era una etapa pasajera en la vida de sus hijos ${ }^{7}$.

Las revistas femeninas oscilaban entre establecer una distancia crítica de las nuevas costumbres y cederles la palabra. Para Ti, desde sus tintes conservadores, publicó en 1968 "Cartas de una madre", en lo que se reflexionaba sobre "los límites de la libertad” (n²420, 21 de noviembre de 1968): “¿Cuáles son los peligros de la libertad para las adolescentes? ¿Cuáles son sus límites? ¿Y quién debe imponer esos límites?" (p. 28).

En una epístola destinada a educar a la hija, la revista presentaba un texto ejemplar, con tono pedagógico y amistoso, donde se enseñaba a las madres acerca de cómo actuar con sus jóvenes hijas, en los intentos por construir un nuevo tipo de relación materna:

\footnotetext{
Ya sabes que en mí tienes una amiga (...) Me gusta que seas más libre que generaciones anteriores (la mía inclusive) (...) Me gusta, sobre todo, que hagas de tu conducta algo valioso en sí mismo, no por tradición o convencionalismos sino por franqueza, por lealtad, por honestidad propias (ibíd.).
}

Los nuevos mandatos traducían una moral impuesta por tradición a una ética de sí asentada en la autovigilancia: "es necesario que mandes en tus sentimientos y en tus actos a fin de ser una mujer cabal cuando dejes de ser una adolescente. La mujer que yo quiero que seas" (ibíd.).

Desde la psicología, Eva Giberti instaba a los padres a comprender que las melenas y los ritmos frenéticos eran expresiones de la vida instintiva de jóvenes que estaban creando un mundo propio, con gustos y demandas particulares (Cosse, 2006). Afirmaba que los adolescentes estaban sufriendo una aceleración, "un adelanto en la maduración biológica", referida a sus vidas sexuales y sus cuerpos.

7 Giberti, 21 de julio de 1964, y Los adolescentes acelerados, mayo de 1966.

8 Los adolescentes acelerados, mayo de 1966, p. 150. 
Asentada en la certeza científica, Giberti otorgaba a las madres algunas "claves para la comprensión de los adolescentes", instando a "tomar conciencia" de lo que esta aceleración significaba: "habituarse a ella en lugar de juzgarla y, sobre todo, comprender que para los adolescentes tampoco resulta fácil hacerse cargo de sus cambios y sus desconciertos" (op. cit., p. 192).

Los años 60 quedaron signados internacionalmente como el decenio de la experimentación, la invención de nuevas posibilidades de vida, a través de la sexualidad, pero también la música o las drogas (Bruckner, 2011). En Argentina, las transformaciones, aunque especialmente trasvasaron a la clase media, fueron transversales a toda la sociedad.

En el plano de la experimentación artística, emergió el happening, un tipo de performance que, según la revista Gente, nadie entendía: “¿Adónde llegará esto?", se preguntaba: “Podemos asegurar que tiene un destino: la locura. Aunque a ellos esto quizás les atraiga aún más. El último sellevó a cabo en el instituto Di Tella y el público, azorado, vio peces, 'amor' y pintura. Júzguelos" (Gente, $\mathrm{n}^{\circ}$ 73, 15 de diciembre de 1966, p. 9).

Grandes imágenes a color mostraban jóvenes de cuerpos semidesnudos entrelazados y mucha espuma. La crónica narraba la escena de la rebeldía asociada a lo artístico:

Era éste un mundo extraño de pelos largos, caras aburridas, esperando que algo sucediera [...] entre los aullidos de los Beatles (...) En el escenario Chela Barbosa se había quitado los zapatos y ahora se arrancaba la falda. Una señora, muy nerviosa, se aferró a la cartera y musitó: "Oh, se está desnudando”. (...) Se quitaban los pantalones. Todos quedaron en bikinis y se fueron contra la pared. Un viejito indignado me dijo: “¿No sería oportuno fusilarlos?"

Los Beatles seguían bramando (...) muchachos y chicas comenzaron a arrojarse pintura. Y después, todos embadurnados comenzaron una extraña danza del amor (p. 9).

La revista de actualidad sometía estas prácticas a juicio pero al mismo tiempo daba prensa a este tipo de manifestaciones. La propia editorial se jactaba, a fines de la década, de haber "logrado enlazar en las páginas de nuestra revista notas sobre jubilados simultáneamente con expresiones juveniles de última onda (...) El público nos entendió porque nadie es totalmente serio o puramente alegre" (Gente, nº 193, 3 de abrilde 1969, p.7). Entonces, la revista proclamaba estar destinada a: "Gente joven sin tener en cuenta la edad, inquieta, unida e interesada en todo el quehacer nacional, gente que no quiere quedarse atrás, que no quiere nada híbrido, soso o envasado" (ibíd.).

En la época también florecía el hippismo, especialmente en Europa y Norteamérica. Rebeldes, pacifistas y defensores del amor libre, en oposición al hombre unidimensional que denunciaba Herbert Marcuse (1993 [1954]), se proponían, entre otras cosas, alterar la vida privada y retar las costumbres pú- 
blicas, promover el amor y experimentar el erotismo. Arremetieron contra la pareja, la familia, el trabajo industrial en serie, el Estado y la vida urbana. En este punto, según Barrancos: "Su radicalidad, en relación con el orden íntimo, anclaba en una transformación de las costumbres domésticas, por lo que se retomaban muchos signos libertarios" (2010, p. 212). Al menos en apariencia, el hippismo exhibía relaciones menos jerarquizadas entrelos sexos. Exprimentando a la marihuana y al LSD, predicaban el amor y no la guerra.

El flowerpower se fusionó con la cultura pop, difundiéndose con la música y la imagen de Los Beatles a partir de 1966. Las revistas de actualidad como Life o Gente dedicaban artículos que interpretaban este movimiento. A fines de la década, Gente prometía exponer en una nota: "Qué hacen, qué piensan, qué hablan, qué comen" Yoko Ono y John Lennon (Genten ${ }^{\circ}$ 194, 10 de abril de 1969, pp. 38 y 39), tal como si se tratara de extraterrestres.

En Argentina el hippismo conformó un estilo. Asociado a la música beat -aún no había prendido la expresión "rock nacional”-, el hippie argentino no podía oponerse a la abundancia como hacía su par norteamericano, pero sí a un clima social y moral asfixiante. Poco interesado por la política, rechazaba al conformista y al pragmático, la vida de oficina, el matrimonio, la disciplina del trabajo y la moral sexual de los mayores. La experimentación con las drogas cobraba relevancia bajo el supuesto de que éstas expandían los límites dela conciencia, favoreciendo así una percepción más rica y compleja de la realidad.

La experimentación con estupefacientes tenía sus figuraciones en los discursos publicitarios, imponiendo una estética psicodélica (figura 3). Sin embargo, hacia 1970, las informaciones sobre su tráfico y consumo trasvasaronla curiosidad de las prácticas rebeldes para instalarse definitivamente en las secciones policiales de los diarios. Simultáneamente se consolidaba lo que Beatriz Preciado (2010) denominó como un capitalismo farmacopornográfico, con un mercado capaz de gestionar tecnológicamente la vida íntima, sexual asociada al consumo de drogas legales e ilegales.

Figura 3. Pasémonos al Suavegom. Publicidad Suavegom, 1969.

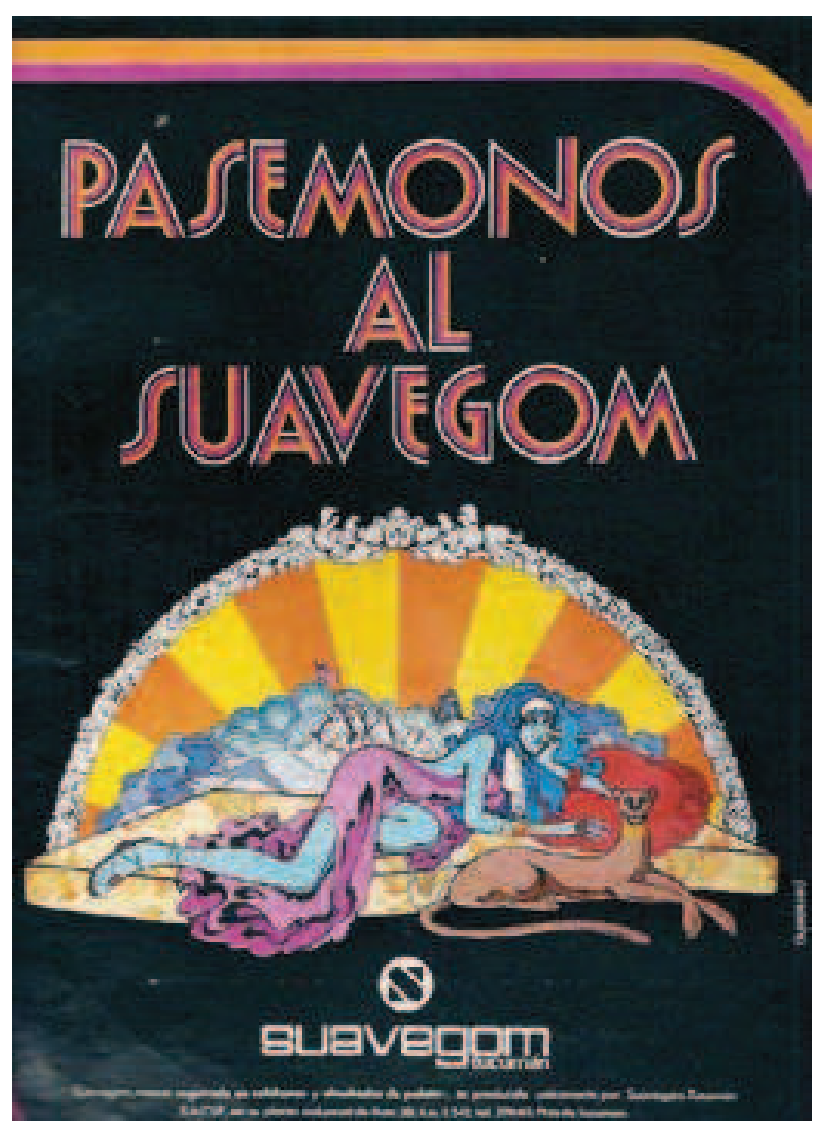


Las investigaciones sociales también pusieron su lupa en la juventud, imbuidas por el lenguaje de la revolución, otro tópico de época. Herbert Marcuse (1986 [1967]) estaba convencido que esta revolución vendría con y por los jóvenes. La esperanza en los cambios se ponía en manos de la juventud. El mito juvenilista se desarrollaba por todos los frentes. La ciencia y, sobre todo, el mercado capitalista en plena mutación harían un uso intensivo de ély lo afianzarían como herencia sesentista para las décadas subsiguientes.

Con la estética juvenil una auténtica mítica del ser joven había brotado con fuerza (Pujol, 2002; Terán, 2008). El ámbito publicitario en su apogeo cooptó rápidamente estas tendencias, poniendo profusamente en imágenes los valores relativos a una sociabilidad juvenil relajada y flexible. Los avisos publicitarios en las diferentes revistas ${ }^{9}$

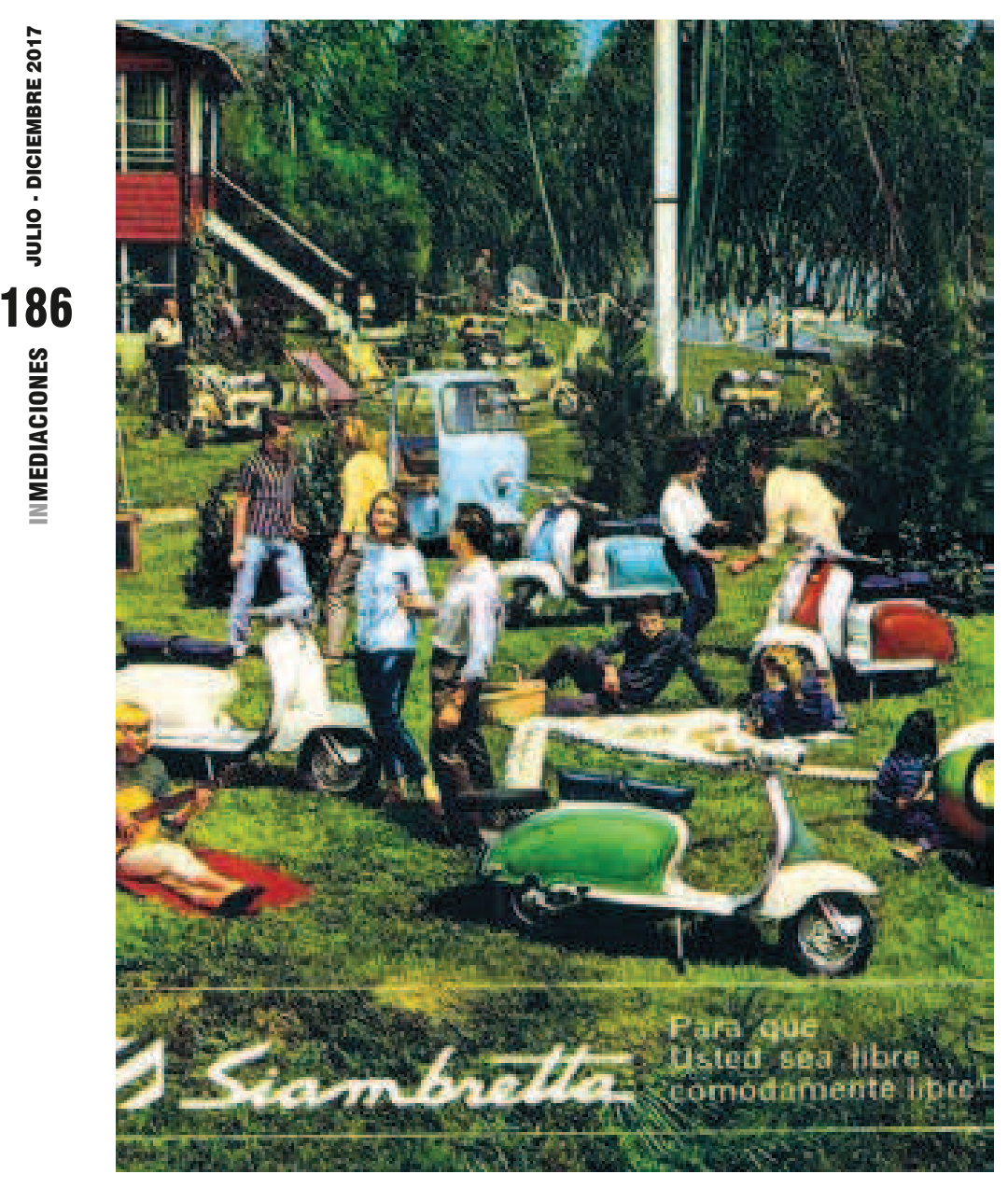
mostraban el avance de la informalidad. Hasta las marcas más tradicionales agregaban un tinte juvenil a sus imágenes.

vUn anuncio de motos Siambretta (figura 4) presentaba jóvenes danzando, tocando la guitarra, de picnic, cerca del río, con atuendos coloridos, bajo el slogan: "Para que Usted sealibre...cómodamentelibre" (Publicidad Siambretta, 1960). Lo juvenil se constituía como consumo cultural, y los jóvenes eran valorizados por el naciente marketing no sólo como sujetos de consumo (Pujol, 2002), sino también como objetos de consumo. El mercado ofrecía toda una moda que oficiaba de símbolo de distinción respecto del mundo adulto ${ }^{10}$.

Figura 4. Publicidad Siambretta, 1960.

9 Estos anuncios, como parte de las campañas publicitarias, aparecían en diferentes revistas. No interesa tanto aquí todas las editoriales que los publicaban, sino la construcción de sentidos de estos anuncios como partes de un contexto cultural de época.

10 La noción de teenager, acuñada en la década del 40, describía un nuevo segmento demográfico del mercado de consumo. Beatriz Preciado (2010) sostiene que desde este enfoque, lo importante dela adolescencia no era la edad, sino su capacidad de consumir sin restricciones morales. 
Lo joven se asociaba a lo alegre y colorido, divertido, feliz. En las revistas femeninas, el protagonismo publicitario que tenía antaño la figura de la madre había dado paso a la imagen de la mujer joven e independiente con sus ansias de libertad y placer individual. La espontaneidad se construía de modo que en las imágenes publicitarias las muchachas parecían relajadas (figura 5).

Figura 5. Un día, un auto. Publicidad Citroën, 1968.

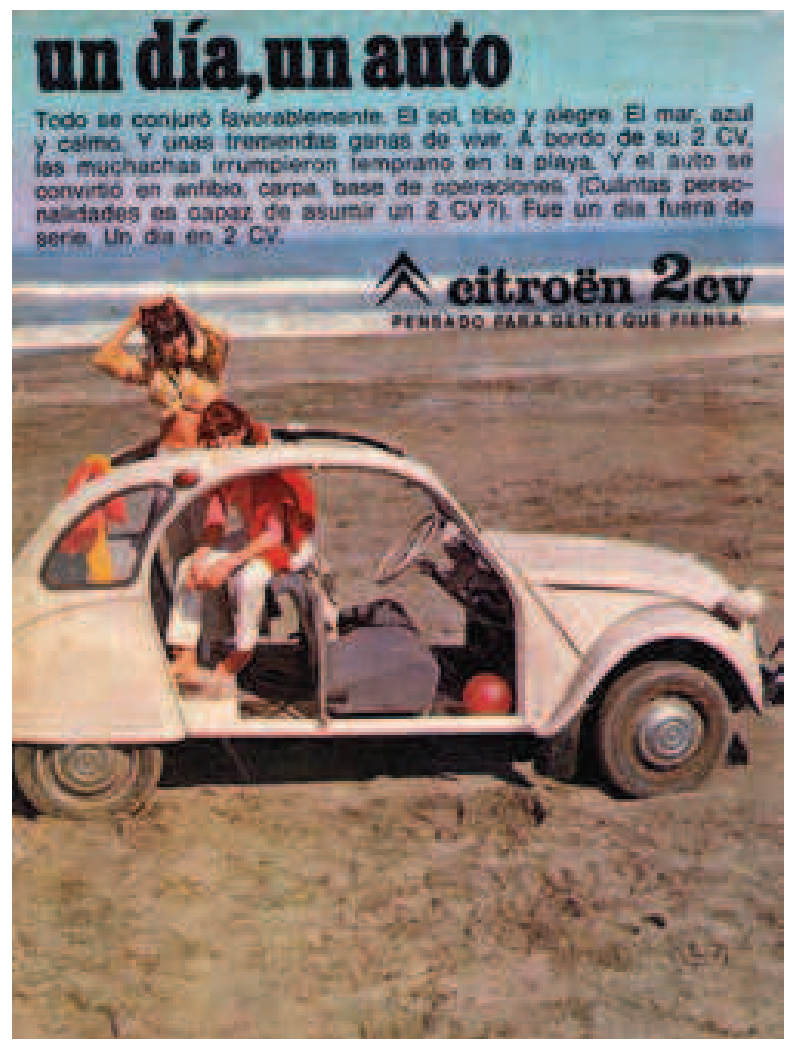

Lo juvenil se asociaba a cuerpos en movimiento y el baile era parte de esta configuración de sentidos. Desde principios dela década se difundieronlocales bailables nocturnos, identificados como epítomes de los cambios en la moral sexual, en la medida en que se asociaban visualmente con una sexualidad juvenil más desenfadada, no atada a los mandatos de virginidad prematrimonial vigentes en la década anterior.

El baile era otro espacio de confrontación con el mundo viejo-tradicional. Mientras varones y chicas reclamaban su derecho al disfrute a través de la música, muchos adultos remarcaban los supuestos peligros que el nuevo baile implicaba para la moral sexual de la juventud. El rock naciente se asociaba a música y bailes voluptuosos.

Algunos agentes estatales, grupos católicos y partidos de izquierda advertían sobre la amenaza que representaba para la cultura nacional. Las ideas de degeneración y desorden moral estructuraron parte de la crítica que el rock recibió inicialmente. Las danzas frenéticas no debían ser permitidas ante los peligros de una sexualidad juvenil abierta y de las posibles actitudes desafiantes que generaría en los y las jóvenes.

Pero entonces, un segmento creciente de la industria cultural nacional fue clave para hacer del rock una práctica aceptada y respetable. Fue entonces cuando se gestó la nueva ola juvenil nacional como una traducción autóctona de la nouvelle vague. De esta manera, los medios gráficos y los empresarios del 
entretenimiento buscaron contener al rock y hacerlo un estilo musical aceptable para los jóvenes en la familia.

Con las estrategias de contención centradas en integrar el rock en una serie de ritmos bailables o cantables, que no entraran en colisión con las tradiciones, se promovió el exitoso Club del Clan. En un paisaje mediático en expansión, la nueva ola juvenil transmitía cierto optimismo edulcorado, reforzando un imaginario tradicional sobre los roles de género, celebrando el amor romántico, mientras ocluía toda referencia a la sexualidad y desdibujaba la percepción de rebelión asociada a la juventud. Prevalecía el conservadurismo cultural, apenas escondido tras una pátina de renovación juvenil. Los mandatos explícitos de esa propuesta se centraban en la adecuación a los roles de género, valores familiares establecidos y en el deseo de divertirse ordenadamente, con decoro sexual (Varela, 2005; Manzano, 2010).

Burlando estas estrategias de contención otros jóvenes talentos hicieron su irrupción en la escena mediática. Uno de ellos, Roberto Sánchez-alias Sandrose aventuró por senderos más arriesgados en términos estéticos y sexuales, probando los límites de lo permisible en la cultura pública argentina de los primeros años de los años 60. Las evocaciones a la pasión y el desborde, tanto musical como sexual, y lo excesivo de sus movimientos corporales, tildados de obscenos, constituyeron las marcas con las que Sandro se presentó durante la década. El baile se inscribía como un acto corporal subversivo, asociado, como ritual social, a una forma de conquista y cortejo con fines sexuales (Lenarduzzi, 2012).

\section{FIN DE LA FIESTA: REPRESIÓN Y CENSURA DEL EROTISMO}

Tras el golpe de estado de Onganía y la intervención a las universidades, la tensión entre los jóvenes y el poder político se incrementó dramáticamente en los últimos años de la década. Al tiempo que en las calles de París, en 1968, muchos jóvenes gritaban "Prohibido prohibir" y "La imaginación al poder", en Argentina crecían las movilizaciones estudiantiles. En mayo de 1969, el Cordobazo y el Rosariazo encontraron a jóvenes y obreros en una alianza que se materializó en movilizaciones y medidas de lucha compartidas.

La sociabilidad informal que identificaba a la juventud comenzó a estar cada vez más signada por el avance de la violencia y la represión. A fines de la década, la censura, la radicalización cultural y la polarización política daban fin a la década rebelde (Pujol, 2002), tras el relevo de Onganía y el secuestro y ejecución del ex presidente de facto, Pedro Eugenio Aramburu en 1970.

Frente a las transformaciones de esta década disruptiva en el país se había incrementado la represión moralista y el autoritarismo. Antela debilidad delos gobiernos democráticos y la inestabilidad política, la presencia amenazadora de las Fuerzas Armadas instaló un clima crecientemente represivo en el que 
comenzaron a ser considerados peligrosos ciertos cambios en las costumbres familiares, de género y sexuales, en tanto atacaban los pilares morales forjados por la idea de una nación católica.

Las campañas de moralización tuvieron a la juventud como blanco principal (Eidelman, 2015). Los jóvenes habían dejado de representar el valor de promesa para el desarrollo y comenzaban a ser definidos como un problema: "En verdad, para las autoridades el delito principal era ser joven. La juventud era vista como una categoría revolucionaria per se" (Pujol, 2002, p. 56).

El campo cultural fue un foco de intervención de la represión estatal. Se detenía a mujeres por llevar polleras excesivamente cortas o a jóvenes acusados de tener sexo en espacios públicos. Se organizaban cortes de pelo a la fuerza, cobro de multas a los melenudos, excursiones de los policías por los albergues transitorios; se clausuraban locales de diversión nocturna. En este contexto se fue generando una suerte de 'pánico sexual' (Rubin, 1989), cruzado por temores sociales, olas de rumores y versiones alarmistas (Eidelman, 2015). La represión era en gran parte una respuesta violenta a la expansión de posibilidades sexuales ${ }^{11}$.

La cruzada moralizante censuraba los discursos eróticos en los medios de comunicación. La censura legitimaba al Estado en tanto evaluador de las expresiones culturales, condicionando a la producción editorial a mesurar sus publicaciones relacionadas a temas eróticos:

\begin{abstract}
Para una sociedad fuertemente vigilada por la Iglesia católica y el Ejército, tocar estos temas no era poca cosa. En ciertos ámbitos, hablar o escribir sobre sexo podía resultar más transgresor que elogiar al Che Guevara y la Revolución Cubana o hacer referencias a la figura de Perón, el gran exiliado nacional. Después del 66, bajo el régimen de Onganía, la censura moral fue tan fuerte o más que la censura política (Pujol, 2002, p. 61).
\end{abstract}

Se perseguía el erotismo y la pornografía, denunciados de constituir una herramienta de penetración del comunismo en la sociedad, a través de la subversión de la moralidad pública y las buenas costumbres (Eidelman, 2015). En algunos filmes, como los del director francés Ingmar Bergman, ciertas escenas fueron recortadas por atentatorias "contra el pudor medio" (Pujol, 2002, p. 209), puesto que el sexo era mostrado de un modo que, para los criterios imperantes en la época, podía considerarse explícito. También la película Blow up, de Michelangelo Antonioni, fue truncada, así como Sexus de Henry Miller, Lolita de Vladimir Nabokov, Ojo mágico de Asimov.

Mientras la censura cinematográfica era algo corriente, en la prensa, el Instituto Verificador de Circulaciones monitoreaba las publicaciones. La au-

$11 \mathrm{Al}$ frente de un organismo ad hoc de la Policía Federal dedicado a este tipo de persecución, la permanencia del comisario Luis Margaride en los gobiernos de Frondizi (1959-1962), Guido (1962-1963), Onganía (1966-1970) y Perón (1973-1974) demostraba que el clima represivo en este área de la vida social excedía las distinciones entre gobiernos civiles y militares, democráticos o golpistas (Felitti, 2012). 
tocensura funcionaba aceitadamente dentro de las redacciones y los autocondicionamientos se justificaban bajo el argumento de que pocos empresarios editoriales podían arriesgar el costo de inversión de un producto que luego no podría ingresar al mercado. Mediante la mesura la prensa intentaba no traspasar los límites de lo que consideraba aceptable para su público y para su gobierno.

No obstante los recaudos que tomaban las editoriales, los sectores más conservadores seguían viendo en ellas potenciales peligro. De acuerdo con el Secretariado Central de Moralidad dependiente de la Acción Católica Argentina, entre las revistas femeninas, Claudia estaba dentro de la categoría de publicaciones desaconsejables, mientras que Vosotras, Idilio y Anahí calificaban directamente como malas. Para Ti era la única que se consideraba apropiada para las mujeres adultas (Felitti, 2010).

La censura habilitaba asimismo las detenciones de periodistas, las querellas con los medios y las clausuras temporarias o definitivas de revistas y diarios como Cristianismo y Revolución, Inédito, Azul y Blanco, Así, Crónica, Primera Plana, Ojo, Prensa Confidencial y sus sucesoras Prensa Libre y Prensa Nueva. La revista Adán (un estilo de revista Playboy argentina) no fue clausurada, pero su éxito duró poco tiempo en medio de condiciones represivas. Resultaba claro que el contexto político no era el más adecuado para una revista que establecía, casi como una declaración de principios de una nueva masculinidad, el disfrute hedonista de los placeres del cuerpo. Una publicación de este tipo debía discutir con los censores del gobierno militar "cuántos centímetros de piel libre podían exhibir las modelos” (Ulanovsky, 1997, p. 27).

Los materiales gráficos calificados de inmorales y obscenos eran censurados y secuestrados de los lugares de venta. En su mayoría eran publicaciones para hombres; provenientes de Estados Unidos y que incluían una gran cantidad de fotografía erótica o considerada pornográfica, con desnudos femeninos, semidesnudos o fotos con gestos, poses y actitudes sexualmente insinuantes ${ }^{\mathbf{1 2}}$. Varias de esas publicaciones tenían más de una década de existencia y habían surgido con el mercado de masas para las revistas pornográficas y de fotografía erótica y pin-up. El mayor ejemplo era la revista Playboy, surgida de 1953 y convertida rápidamente en la revista más vendida e importante del género.

Paradójicamente, en nombre de la defensa contra la subversión comunista se prohibía material pornográfico proveniente de la principal potencia capitalista, asociado a la mercantilización del sexo y no a la penetración del comunismo (Eidelman, 2015). En cuanto a las editoriales locales, desde el Ministerio del Interior, a comienzos de marzo de 1969, se les solicitó morigerar la exhibición de todo tipo de expresiones e imágenes eróticas calificadas

12 De 69 revistas prohibidas entre julio y diciembre de 1966, 63 (es decir, un 90\%) eran norteamericanas (Eidelman, 2015). 
como un "reflejo" de la "alarmante evolución de las costumbres" (Ulanovsky, 1997, p. 189).

La campaña de moralidad buscaba recuperar los valores religiosos tradicionales y el lugar de la familia como institución fundamental de la sociedad. para enfrentar lo que se consideraba la degradación cultural y moral de la sociedad y, en especial, de la juventud, fuertemente asociada por los sectores conservadores a una sexualidad más liberal y con menos prejuicios. En las manifestaciones de libertad sexual veían la semilla de la subversión a los valores occidentales y cristianos, y en nombre de la moral, encontraban la justificación de sus intervenciones.

El ideal de familia promovido por el Estado tenía como pilar el matrimonio monógamo y heterosexual y sostenía una clara división de los roles de género: un varón proveedor y una mujer, madre, ama de casa y una descendencia numerosa educada en los valores de la cristiandad. Los mensajes que subvirtieran este modelo podían ser considerados como un ataque a la identidad nacional, la moral y las buenas costumbres. Así iba construyéndose una definición de cultura legítima, verdadera, nacional, y que debía defenderse de la penetración ideológica extranjera y su modelo de sexualidad, que inducía a la perversión, al adulterio y al desamor filial (Felitti, 2012). En un contexto de complejas conexiones entre los cambios culturales en torno al erotismo y el refuerzo de la censura, ésta última instaba a reconocer la dimensión política de la vida erótica, visible en momentos en que se desatan conflictos en torno a los discursos e imágenes eróticas.

La cruzada moral buscaba censurar la conducta erótica para proteger las fronteras de la conducta sexual aceptable. Además, la censura reforzaba el poderoso tabú sobre la puesta en discurso o la puesta en escena de las actividades eróticas; un problema que involucraba tanto una teoría de la imagen como una teoría de la comunicación.

Aunque la idea de un público fácilmente manipulable estaba en plena revisión en el campo de los estudios de comunicación, buena parte de la sociedad seguía considerando que los medios eran capaces de influir de manera determinante en las conductas sociales. Bajo este presupuesto se justificaba una censura que no dejaba de dar preeminencia al poder delos medios. Como teoría de la manipulación mediática, partía de un muy difundido sentido común académico apoyado en una cierta lectura del conductismo y de la teoría de los efectos mediáticos masivos ${ }^{\mathbf{1 3}}$.

La convicción sobre el poder manipulador de los medios de comunicación y los productos de la industria cultural para generar cambios en la conducta

13 Pero entonces, hay que decir que ni siquiera los investigadores conductistas de los años 30 suponían que había un efecto directo por parte de los medios de comunicación capaz de condicionar a sus receptores en un necesario mismo sentido. Esta simplificación era impensable desdela misma teoría conductista, pues ella suponía una suerte delugar de mediación para que se diera respuesta a un estímulo (Homans, 1990); nunca se trataba de una respuesta automática. 
guiaba la censura estatal. La desconfianza también caló hondo en intelectuales y pedagogos, políticos y sacerdotes, proclives a una postura apocalíptica respecto de los medios. Las críticas se hicieron oír tanto en el pensamiento progresista -con todos los matices de la izquierda-como de la derecha conservadora que veía en ellos unos propagadores de la perversión y la deformación de los valores del ser nacional (Pujol, 2002).

Los niños fueron el objeto privilegiado de los discursos de educadores, psicólogos, sacerdotes que alertaban sobre esta influencia. El problema de la seducción del inocente (Spigel, 1992) funcionaba como presupuesto para habilitar la censura mediática por parte de un aparato de vigilancia estatal y así proteger las fronteras de la conducta sexual aceptable:

Comenzaron a multiplicarse los congresos y la bibliografía sobre la influencia en los niños fue, sin duda, la más abultada de la época en el tema de los medios, tanto en los grupos que provenían del catolicismo y el conservadurismo - desde una mirada moralista- como en los sectores progresistas [,] con los conceptos políticos claves de "alienación” y "manipulación” (Aguilar, 1999, p. 262).

Con la excusa de proteger a los niños y la sexualidad de los jóvenes, los discursos de la censura estigmatizaban las prácticas eróticas que se ubicaban fuera de la 'normalidad'. Así exponía la revista Life estos conflictos en torno al erotismo en los medios de comunicación, en su sección de Educación Sexual de 1968:

Cuando no existía la comunicación instantánea por medio de la televisión, la radio y la prensa, los padres encarnaban ante sus hijos en la casa los papeles sexuales, que por lo general eran claros y constituían una parte importante en el proceso de sexualización. Hoy, en muchas partes del mundo, la comunicación instantánea lleva cada vez más al hogar mensajes sexuales múltiples, confusos y a menudo bastante alejados de la educación sexual que los padres tratan de dar a sus hijos. Muchos de los mensajes subrayan la sexualidad erótica y genital a expensas de otros muchos aspectos de la sexualidad. Estos mensajes llegan constantemente a los niños en su más tierna infancia, aun antes que sepan si son varones o hembras: el niño de 3 años edad, huérfano de padre, se sienta ante un receptor de televisión y contempla un grupo de cantantes de rock 'n' roll delarga melena, vestidos con ropa muy rara (para varones) y que a veces cantan con voz atiplada, como de mujer. ¿Puede este niño estar seguro de que los cantantes son varones aunque los mismos cantantes estén seguros de su masculinidad? (Nacemos ya sexuales. Life, 7 de octubre de 1968, p. 58).

Estos tipos de discursos no dejaban de augurar el caos en caso de no seguir sus preceptos, bajo un supuesto del dominó del peligro sexual (Rubin, 1989). Expresaban el temor de que si se cruzaba la frontera, la barrera levantada contra el sexo peligroso se derrumbaría y ocurriría alguna catástrofe inimaginable. 
Pero entonces, el halo del erotismo atravesaba los discursos de la censura. Por el lado de los censores puede presuponerse un goce, ya que, como Michel Foucault (2011a) demostró, hay placer tanto en el preguntar, vigilar, controlar, espiar, denunciar los placeres prohibidos como en su transgresión, su resistencia, su escándalo. La censura y la mesura empujaban al discurso sexual a la reticencia y al eufemismo, conformándose una negatividad sexual (Rubin, 1989); pero, por otro lado, obligaban a potenciar el ejercicio de la capacidad, la inteligencia, la curiosidad y la creatividad erótica para sortear las prohibiciones. Frente a estas actitudes, el erotismo, asentado en la transgresión (Bataille, 2010), tenía un campo de cultivo que hacía uso del ingenio para legitimar el placer.

La censura no significó que la circulación de los discursos eróticos quedara suspendida, pues más allá de las represiones de la coyuntura, había una dinámica cultural imposible de frenar: "No obstante los obstáculos puestos por el gobierno militar contra la agenda de temas modernos, la sociedad argentina se fue abriendo cada vez más al diálogo sobre lo prohibido y lo incómodo" (Pujol, 2002, p. 62).

Los temas de sexualidad no desaparecieron de las pantallas, las revistas y la literatura, prevaleciendo una distancia y un desfase entre los discursos, las normativas y su implementación. Ante las ambigüedades y la falta de seguimiento de muchas disposiciones, algunos productos de la industria cultural sortearon la censura y pusieron en escena tópicos tabú, brindando información y habilitando debates (Felitti, 2012).

Las editoriales no eludían la presentación de los conflictos en torno al sexo, siempre que se hiciera con moderación. En este marco, los discursos de la sexualidad como el psicoanálisis contaban con una legitimación y una autoridad que los hacía gozar de una permisividad social. Las narrativas e imágenes del erotismo tenían lugar entre las páginas de las revistas femeninas, especialmente en las novelas rosas y las publicidades que hacían uso de figuraciones más jugadas.

Al convertirse el erotismo en un objeto de preocupación, de análisis, de vigilancia y de control, la censura lograba intensificar el deseo por el mismo, atizando su potencial erótico. El propio juego de la transgresión hacía que los placeres perseguidos, culposos, fueran a la vez hostigados y deseados. Este contexto de época, signado por una industria cultural en crecimiento, la proliferación de revistas femeninas, la emergencia y consolidación de un mito que aunaba juventud y rebeldía, junto a la censura y la represión, componían las condiciones de producción de los discursos eróticos en las revistas femeninas de los años 60 . 


\section{REFERENCIAS}

Aguilar, G. (1999). Televisión y vida privada. En Fernando Devoto y Marta Madero (directores), Historia de la vida privada en La Argentina, Tomo III (pp. 255-283) Buenos Aires: Taurus.

Ballent, A. (2011). El mundo de Claudia. La modernización cultural de los años sesenta y setenta. Todavía, Pensamiento y Cultura en América Latina, 25. Recuperado: 22/5/2014. En línea: http://www.revistatodavia.com.ar/todavia25/25. historianota.html

Barrancos, D. (2010). Mujeres en la Sociedad Argentina. Una historia de cinco siglos. Buenos Aires: Sudamericana.

Bataille, G. (2010 [1957]). El Erotismo. Buenos Aires: Tusquets.

Bontempo, P. (2011). Para Ti: una revista moderna para una mujer moderna (19221935). Estudios Sociales, 41, 127-156. Recuperado: 08/10/2015. En línea http:// bibliotecavirtual.unl.edu.ar/ojs/index.php/EstudiosSociales/article/viewF ile/2684/3848

Bruckner, P. (2011).Laparadoja delamor. Una reflexión actual sobrelaspasiones. Buenos Aires: Tusquets.

Campillo, A.(1996). Elamorde unsermortal.En Georges Bataille(1996), Loqueentiendo por soberanía (pp. 9-54). Barcelona: Paidós/ICE de la Universidad Autónoma de Barcelona, España.

Carrascal, M. L. (2010). Un nuevo modelo de mujer reflejado en la moda rosarina de los años 60. La Trama de la Comunicación, 14, 95-107.

Cingolani,G.(2008).Tapasdesemanariosargentinosen el sigloXX:historiadiscursivade undispositivoy dosmedios. RevistaLIS. LetraImagen Sonido.CiudadMediatizada, 1(1), 83-92. Recuperado:28/1/2015. En línea http://semioticafernandez.com.ar/ wp-content/uploads/2010/09/7-LIS1- TapasSemanarios-GC.pdf

Cosse, I. (2006). Cultura y sexualidad en la Argentina de los 60. Usos y resignificaciones de la experiencia trasnacional. Estudios interdisciplinarios de América Latina y el Caribe, 17(1), 39-60.

Cosse, I. (2010). Pareja, sexualidad y familia en los años sesenta. Una revolución discreta en Buenos Aires. Buenos Aires: Siglo XXI.

Cosse, I. (2011). Claudia: la revista de la mujer moderna en la Argentina de los años sesenta (1957-1973). Mora, 17(1). Recuperado: 1/7/2014. En línea http://www. scielo.org.ar/scielo.php?Script=sci_arttext\&pid=S1853-001X2011000100007\& $\operatorname{lng}=\mathrm{es} \& \mathrm{nrm}=\mathrm{iso}$

Diviani, R. (2010). Ciencias sociales y comunicación de masas. Algunos apuntes sobre la constitución del campo de estudio sobre comunicación en Argentina y sus 
derivas. Question, 26. Recuperado: 8/10/2015. En línea: http://perio.unlp.edu.ar/ ojs/index.php/question/article/view/957

Eidelman, A. (2015). Moral católica y censura municipal de las revistas eróticas en la ciudad de Buenos Aires durante la década del sesenta. En Débora D'antonio (comp.) Deseo y represión. Sexualidad, género y Estado en la historia argentina reciente (pp. 1-20). Buenos Aires: Imago Mundi.

Felitti, K. (2010). El control de la natalidad en escena: anticoncepción y aborto en la industria cultural de los años sesenta. En Isabella Cosse (et al.), Los '60 de otra manera. Vida cotidiana, género y sexualidades en la Argentina (pp. 205-244). Buenos Aires: Prometeo.

Felitti, K. (2012). La revolución de la pildora: sexualidad y política en los sesenta. Buenos Aires: Edhasa.

Friedan, B. (2009 [1963]). La mística de la feminidad. Valencia: Cátedra.

Gilman, C. (2003). Los sesenta / setenta considerados como época. En La pluma y el fusil (pp. 35-56). Buenos Aires: Siglo XXI.

Homans, G. (1990). El conductismo y después del conductismo. En A. Giddens (comp.), La teoría social hoy (pp. 81-111). Alianza: México.

Kosak, C. (2006). Los60. En Paulo Ricci (et. al.), Cuando los 60 fueron jóvenes. Literatura y política en la década del '60 (pp. 167-169). Paraná: Universidad Nacional de Entre Ríos.

Lenarduzzi, V. (2012). Placeres en movimiento: cuerpo, música y baile en la escena electrónica. Buenos Aires: Paidós.

Manzano, V.(2010).Hallegadola 'nueva ola':música, consumoyjuventudenla Argentina, 1956-1966. En Isabella Cosse (etal.), Los'60 de otra manera. Vida cotidiana, género y sexualidades en la Argentina (pp. 199-60). Buenos Aires: Prometeo.

Marcuse, H. (1986 [1967]). El final de la utopía. Barcelona: Planeta Agostini.

Marcuse, H. (1993 [1954]). El hombre unidimensional. Buenos Aires: Planeta.

Marzano, M. (2006). Lapornografía o el agotamiento del deseo. Buenos Aires: Manantial.

Mattelart, A. (1991). La Publicidad. Barcelona: Paidós.

Mouffe, C. (2009). En torno a lo político. Buenos Aires: Fondo de Cultura Económica.

Muchembled, R. (2008). El orgasmo y occidente. Una historia del placer desde el siglo XVI a nuestros días. Buenos Aires: Fondo de Cultura Económica.

Preciado, B. (2010). Pornotopía. Arquitectura y sexualidad en 'Playboy' durante laguerra fría. Barcelona: Anagrama. 
Prada, N. (2010). ¿Qué decimos las feministas sobre la pornografía? Los orígenes de un debate. La manzana de la discordia, 5(1), 7-26.

Pujol, S. (2002). La década rebelde. Los años 60 en la Argentina. Buenos Aires: Emecé.

Rubin, G. (1989). Reflexionando sobre el sexo: notas para una teoría radical de la sexualidad. En Carole Vance (comp.), Placer y peligro. Explorando la sexualidad femenina (pp. 113-190). Madrid, Ed. Revolución.

Sarlo, B. (2011 [1985]). El imperio de los sentimientos. Buenos Aires: Siglo XXI.

Spigel, L. (1992). Making room for TV. Television and Family Ideal in Postwar America. Chicago: University of Chicago Press.

Terán, O. (2008). Historia de las ideas en Argentina. Diez lecciones iniciales, 1810- 1980. Buenos Aires: Siglo XXI.

Trebisacce, C. (2010). Una segunda lectura sobre las feministas de los'70 en Argentina. Conflicto Social, 4(3), 26-52. Recuperado: 08/10/2015. En línea http://biblioteca. clacso.edu.ar/Argentina/iigg- uba/20120621044617/conflicto_social_04.pdf

Ulanovsky, C. (1997). Paren las rotativas: Una historia de grandes diarios, revistas periodistas argentinos. Buenos Aires: Espasa.

Vance, C. S. (1989). El placer y el peligro: hacia una política de la sexualidad. En Carole Vance (comp.), Placer y peligro. Explorando la sexualidad femenina (pp. 8-49). Madrid: Revolución.

Varela, M. (2005). La televisión criolla. Desde sus inicios hasta la llegada del hombre a la Luna (1951-1969). Buenos Aires: Edhasa.

Verón, E. (1984). Semiosis de lo ideológico y del poder. Espacios de crítica y producción, Cuadernos de la Facultad de Filosofía y Letras, Universidad de Buenos Aires (UBA), pp. 43-51.

Verón, E. (2004). Prefacio. En Mario Carlón, Sobre lo televisivo (pp.7-14). Buenos Aires: La Crujía.

\section{HEMEROGRAFÍA}

¿Adónde llegará esto? (15 de diciembre de 1966). Gente, 73(1), 9-10.

A todo color (26 de diciembre de 1968). Gente, 179(4), portada.

Barrancos, D. (14 de diciembre de 2011). El erotismo, una conquista feminista muy reciente. Clarín. Recuperado: 14/12/2011. En línea http://www.entremujeres. com/genero/erotismo-conquista-feminista-reciente_0_494950559.html

Giberti, E. (21 de julio de 1964). Adolescencia liberal. Maribel, 1637(33), 24. 
Karina (15 de mayo de 1969). Gente 199(4), 24.

Los adolescentes acelerados (mayo de 1966). Femirama, 8(1), 150 y 151.

Los límites de la libertad (21 de noviembre de 1968). Para Ti, 2420(46), 28.

Nacemos ya sexuales (7 de octubre de 1968). Life, 32(1), 52-58.

Publicidad Citroën, 1968.

Publicidad Siambretta, 1960.

Publicidad Suavegom, 1969.

Qué hacen, qué piensan, qué hablan, qué comen (10 de abril de 1969). Gente, 194(4), 38. Vosotras (8 de octubre de 1959). 1244(24), portada.

María Laura Schaufler es Doctora en Comunicación Social por la Universidad Nacional de Rosario (UNR), Argentina y Licenciada en Comunicación Social por la Universidad Nacional de Entre Ríos (UNER), Argentina. Es Becaria postdoctoral del Consejo Nacional de Investigaciones Científicas y Técnicas (CONICET), Argentina, y miembro del Centro de Investigación en Mediatizaciones (CIM), Facultad de Ciencias Políticas y Relaciones Internacionales, UNR. Es docente de la cátedra "Investigación en Comunicación", Facultad de Ciencias de la Educación, UNER, y desarrolla tareas de investigación en el campo de la semiótica de los medios masivos. Su proyecto de investigación CONICET se titula: "Sentidos de lo erótico en la prensa digital femenina en el contexto de las mediatizaciones actuales en Argentina".

\section{REGISTRO BIBLIOGRÁFICO}

Schaufler, M. L. (2017). Erotismo y mediatizaciones. Revistas femeninas en la Argentina la década del 60. InMediaciones de la Comunicación, 12(2), 173-197. 